\title{
Antibacterial Activity of Tinctures from Tree leaves belonging to the Bignoniaceae family and their Synergistic Effect with Antibiotics
}

\author{
Torres Carola Analía ${ }^{1,2}$, Nuñez María Beatriz', Isla María Inés ${ }^{3,4}$, Castro Marcela Paola ${ }^{1,2}$, Gonzalez Ana María ${ }^{1,2,5}$ and Zampini Iris \\ Catiana $^{3,4}$ \\ 'Departamento de Ciencias Básicas y Aplicadas, Universidad Nacional del Chaco Austral (UNCAUS), Comandante Fernández 755-Presidencia Roque Sáenz Peña, \\ Chaco, Argentina. \\ 2Laboratorio de Microbiología de los Alimentos (UNCAUS), Consejo Nacional de Investigaciones Científicas y Técnicas (CONICET), Argentina. \\ ${ }^{3}$ Instituto de Química del Noroeste Argentino (INQUINOA-CONICET), Universidad Nacional de Tucumán. Argentina. \\ ${ }^{4}$ Cátedra de Química Orgánica y Biológica, Facultad de Ciencias Naturales e IML y Facultad de Bioquímica, Química y Farmacia, Universidad Nacional de Tucumán, \\ Ayacucho 471, San Miguel de Tucumán, Tucumán, Argentina. \\ Instituto de Botánica del Nordeste IBONE (CONICET), Sargento Cabral 2131, Corrientes. Argentina.
}

\section{ABSTRACT}

Context: Some species of Bignoniaceae are widely used in medicinal practice by the natives of South America. Aims: Tinctures and infusions from twelve tree species of this family were evaluated for in vitro antibacterial activity against pathogenic bacteria. The effect of interactions between the four most active extracts and conventional antibiotics was also evaluated. Methods and Material: Bioautography and disc diffusion methods were used to select the most active extracts, then agar macrodilution and broth microdilution method were used to determine the minimal inhibitory and minimal bactericidal concentration (MIC and MBC). Time-kill assay and checkerboard method were employed to determine the type of antimicrobial effect and synergism, respectively. Results: It could be determined that tinctures from Catalpa bignonioides, Handroanthus pulcherrimus, Tabebuia nodosa and Tecoma stans were able to inhibit bacterial growth. The MIC and MBC observed were between 125-1000 $\mu \mathrm{g} \mathrm{GAE/}$ $\mathrm{ml}$ and 500-1000 $\mu \mathrm{g} \mathrm{GAE} / \mathrm{ml}$, respectively. The tested extracts were more effective against Gram-positive microorganisms. Time-kill experiments indicated bacteriostatic activity. Phytochemical screening showed terpenoids, phenols and flavonoids. Alkaloids were detected only in Tecoma stans. Among these combinations, the best was Tabebuia nodosa extract plus gentamicin. In most cases, MIC values were reduced 16-32 times for antibiotics, and even 8-16 times for extracts. Conclusion: These results revealed that some of the selected combinations could efficiently inhibit the growth of tested strains at lower concentrations than those required for the lonely use of the antimicrobial. These extracts would improve the efficacy of antibiotics against resistant bacteria, hence they could be used for anti-infective therapy.
\end{abstract}

Key words: Checkerboard method, Fractional inhibitory concentration (FIC), Gentamicin, Tabebuia nodosa, Time-kill experiments.

Key Messages: Plant extracts and antibiotics: a new tool to fight against bacterial infections.

\section{SUMMARY}

- The tinctures of Catalpa bignonioides, Handroanthus pulcherrimus, Tabebuia nodosa and Tecoma stans inhibited bacterial growth.

- MIC and MBC values were between 125-1000 $\mu \mathrm{g}$ GAE (Gallic acid equiva- lent $/ \mathrm{ml}$ and 500-1000 $\mu \mathrm{g} \mathrm{GAE} / \mathrm{ml}$, respectively.

- Phytochemical screening showed terpenoids, phenols and flavonoids. Alkaloids were detected only in Tecoma stans.

- The combination of Tabebuia nodosa extract and gentamicin was the most effective.

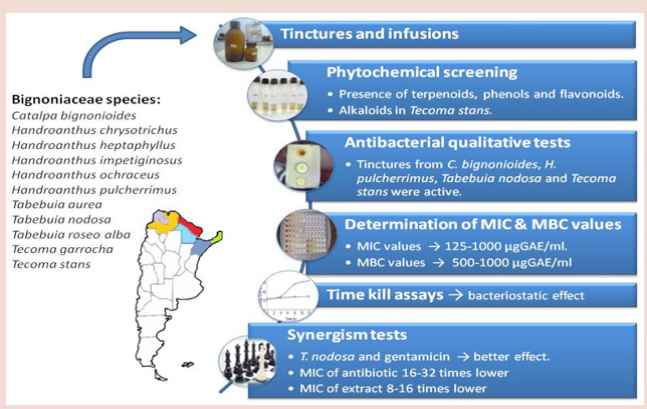

\section{PICTORIAL ABSTRACT}

Abbreviations used: MIC: Minimal concentration inhibitory, MBC: Minimal bactericidal concentration, GAE: Gallic acid equivalent, INOUINOA: Instituto de Química del Noroeste Argentino (Institute of Chemistry of Northwest from Argentina), IBONE: Instituto de Botánica del Nordeste (Northeast Institute of Botany), CONICET: Consejo Nacional de Investigaciones Científicas y Técnicas (National Council of Scientific and Technical Research), ASTM: Association for Testing Materials of United States, ATCC: American Type Culture Collection, DMSO: Dimethyl sulfoxide, CFU: Colony-forming unit, FIC: Fractional inhibitory concentration.

\section{Correspondence:}

Ms. Zampini Iris Catiana, Ayacucho 471, San Miguel de Tucumán, Argentina. Phone no: +54 0381-4203062, Fax no: +54 0381-4203062

Email: zampini@csnat.unt.edu.ar

DOI : 10.5530/pj.2015.6.15

\section{INTRODUCTION}

Medicinal plants represent a rich source of antimicrobial agents. These compounds can be terpenoids, glycosteroids, flavonoids and polyphenols. Most of these molecules have weak antibiotic activity; however, plants fight infections successfully. Hence, it becomes apparent that plants adopt a synergistic strategy to combat infections. ${ }^{1}$

Bignoniaceae Juss. is a family of trees, shrubs or climbers, which is made up of about 100 genera and 800 species. Some species of this family are widely used in medicinal practice by the natives of South America. ${ }^{2,3}$ The well-known medicinally important members of this family are Tecoma, Catalpa, Handroanthus, Tabebuia and Jacaranda. Several species traditionally used have demonstrated to be useful for microbial infections. ${ }^{4-7}$ Torres et al., $2013^{8}$ have previously analyzed the antibacterial properties of 20 climbers of this family.

The aim of this work has been to evaluate the antibacterial effect of the infusions and tinctures of leaves from twelve species of trees belonging to the Bignoniaceae family against pathogenic bacteria. Besides, a study 
of synergistic effects resulting from the combination of tinctures with commercial antibiotics was conducted.

\section{SUBJECTS AND METHODS}

\section{Plant material}

Plant material was collected from the North of Argentine. The voucher specimens were deposited and conserved in the Herbarium of the Instituto de Botánica del Nordeste (IBONE-CONICET), Corrientes, Argentina.

\section{Microorganisms}

Microorganisms used in this work were Staphylococcus aureus ATCC 29213, S. epidermidis ATCC 12228, Enterococcus faecalis ATCC 29212, four clinical isolates of methicillin-sensitive S. aureus (F13, F29, F32 and F33), two methicillin-resistant clinical isolates of $S$. aureus (F7 and F22), Escherichia coli ATCC 35218, Pseudomonas aeruginosa ATCC 27853, antibiotic-resistant clinical isolates of Enterobacter cloacae (F302 and F338), Klebsiella pneumoniae (F364), P. aeruginosa (F305), Proteus mirabilis (F304), and Morganella morganii (F339).

\section{Extraction and preliminary phytochemical investigation}

Leaves were dried at room temperature. Then, dry leaves were crushed and milled until they reached a size between $1.70 \mathrm{~mm}$ and $710 \mu \mathrm{m}$ using ASTM (Association for Testing Materials of United States) sieves. Afterwards, tinctures and infusions were prepared with the obtained powder. Tincture: $20 \mathrm{~g}$ of powder was macerated in $80^{\circ}$ ethanol $(100 \mathrm{ml})$ for 7 days in a dark place at room temperature. Infusion: $5 \mathrm{~g}$ of plant powder was put in contact with boiling water $(100 \mathrm{ml})$ for $20 \mathrm{~min}$. Finally, all extracts were filtered through Whatman $\mathrm{N}^{\circ} 1$ filter paper, centrifuged at $3000 \mathrm{rpm}$ for $5 \mathrm{~min}$ and were stored at $-20^{\circ} \mathrm{C}$ in the dark.

\section{Phytochemical analysis}

The presence of secondary metabolites was assessed according to qualitative standard methods. ${ }^{9,10}$ The total phenolic content was quantified according to Singleton et al., 1999. ${ }^{11}$ Flavonoid content was determined according to Woisky and Salatino, $1998 .^{12}$

\section{Antimicrobial assays}

The qualitative determination of antibacterial activity was assessed by the agar disc diffusion method ${ }^{13}$ and the bioauthography assay ${ }^{14}$ using a spot containing $30 \mu \mathrm{g}$ phenolic compounds of each extract. MIC values of the most active extracts were determined by serial agar macrodilution and broth microdilution method. ${ }^{15}$ The microdilution method was also used to determine MBC values.

The extracts were dried and re-suspended in dimethyl sulfoxide (DMSO, Sigma Aldrich, USA). Dilutions of crude extracts in DMSO (range concentration between 62.5 and $1000 \mu \mathrm{g} \mathrm{GAE} / \mathrm{ml}$ ) were prepared. A growth control of each tested strain and a DMSO control were included. MIC was defined as the lowest concentration of extract at which bacterial growth was not observed after incubation. MBC was defined as the lowest extract concentration at which $99.9 \%$ of the bacteria have been killed. All experiments were carried out in duplicate.

Antibacterial effect was evaluated by the time-kill assay. In this test, a standardized suspension of bacteria $\left(5 \times 10^{5}\right.$ colony-forming unit-CFU-/ $\mathrm{ml}$ ) was added into Müeller-Hinton broth containing the extracts to give a final concentration between $500-2000 \mu \mathrm{g} / \mathrm{ml}$. These mixtures were then incubated at $37^{\circ} \mathrm{C}$ for $12 \mathrm{~h}$ shaking at $200 \mathrm{rpm}$. Aliquots of $0.01 \mathrm{ml}$ of the diluted samples were withdrawn at time intervals $(4 \mathrm{~h})$ for the determination of the number of $\mathrm{CFU} / \mathrm{ml} .{ }^{16}$ Crude extracts were considered to be bactericidal at the lowest concentration which reduced the original inoculum by $\geq 3 \log _{10} \mathrm{CFU} / \mathrm{ml}$ (99.9\% reduction in bacterial population) in $4 \mathrm{~h}$.

\section{Estimation of synergy between plant extracts and antibiotics}

Synergy between extracts and selected antibiotics (ampicillin, gentamicin and oxacillin) was studied by the checkerboard assay method. ${ }^{17}$ Combinations of oxacillin and the extracts were tested only for Grampositive bacteria. The concentrations used in the combinations for each antibiotic ranged from 0.05 to $204.8 \mu \mathrm{g} / \mathrm{ml}$ and for each extract between 15.62 and $500 \mu \mathrm{g} \mathrm{GAE} / \mathrm{ml}$.

MIC values were determined for each antibiotic and for each of these combinations to establish any interaction effect. The FIC (Fractional in-

Table 1: Phenolic and flavonoid content in tinctures and infusions of 12 selected tree species of Bignoniaceae family

\begin{tabular}{|c|c|c|c|c|}
\hline \multirow{2}{*}{ Samples } & \multicolumn{2}{|c|}{ Tinctures } & \multicolumn{2}{|c|}{ Infusions } \\
\hline & $\begin{array}{l}\text { Phenolic compounds } \\
\text { (mg GAE/g DE) }\end{array}$ & $\begin{array}{l}\text { Flavonoids } \\
\text { (mg QE/g DE) }\end{array}$ & $\begin{array}{l}\text { Phenolic compounds } \\
\text { (mg GAE/g DE) }\end{array}$ & $\begin{array}{l}\text { Flavonoids } \\
\text { (mg QE/g DE) }\end{array}$ \\
\hline Catalpa bignonoides & $133.13 \pm 5.8^{\mathrm{a}}$ & $3.07 \pm 0.6^{\mathrm{a}}$ & $124.30 \pm 1.26^{\mathrm{a}}$ & $10.24 \pm 1.32^{\mathrm{a}}$ \\
\hline $\begin{array}{l}\text { Handroanthus } \\
\text { chrysotrichus }\end{array}$ & $73.53 \pm 0.43^{\text {b.c }}$ & $14.23 \pm 0.5^{\mathrm{b}}$ & $59.08 \pm 0.83^{\mathrm{b}}$ & $1.35 \pm 0.32^{b . c}$ \\
\hline H. heptaphyllus & $98.90 \pm 7.9^{\mathrm{i}}$ & $34.29 \pm 2.21^{\mathrm{c}}$ & $90.35 \pm 3.2^{c}$ & $12.90 \pm 2.21^{\mathrm{e}}$ \\
\hline H. impetiginosus (wf) & $66.80 \pm 1.8^{\mathrm{c} . \mathrm{d}}$ & $17.87 \pm 0.38^{\mathrm{d}}$ & $29.99 \pm 2.88^{\mathrm{d}}$ & $1.39 \pm 0.17^{b . c}$ \\
\hline H. impetiginosus(pf) & $63.05 \pm 1.70^{c}$ & $17.64 \pm 0.25^{\mathrm{d}}$ & $35.55 \pm 7.28^{\text {d.e }}$ & $3.66 \pm 0.14^{c}$ \\
\hline H. lapacho & $160.73 \pm 7.80^{\mathrm{e}}$ & $18.78 \pm 1.35^{\mathrm{d}}$ & $145.62 \pm 1.30^{\mathrm{f}}$ & $15.37 \pm 1.65^{\mathrm{f}}$ \\
\hline H. ochraceus & $46.71 \pm 0.58^{c}$ & $6.14 \pm 0.99^{\mathrm{e}}$ & $41.04 \pm 1.56^{\mathrm{e}}$ & $3.02 \pm 0.94^{c . d}$ \\
\hline H. pulcherrimus & $121.41 \pm 10.33^{\mathrm{a}}$ & $36.54 \pm 0.68^{f}$ & $120.47 \pm 1.70^{\mathrm{a}}$ & $13.51 \pm 3.23^{\text {eff }}$ \\
\hline Tabebuia aurea & $25.35 \pm 1.26^{f}$ & $14.99 \pm 0.15^{\mathrm{b}}$ & $40.21 \pm 6.88^{\mathrm{e}}$ & $0.14 \pm 0.02^{\mathrm{b}}$ \\
\hline Tabebuia nodosa & $276.91 \pm 2.36^{\mathrm{g}}$ & $47.67 \pm 2.32^{\mathrm{g}}$ & $42.79 \pm 4.00^{\mathrm{e}}$ & $5.47 \pm 1.40^{\mathrm{g}}$ \\
\hline Tabebuia roseoalba & $131.12 \pm 5.87^{\mathrm{a}}$ & $29.95 \pm 1.94^{\mathrm{h}}$ & $192.17 \pm 4.76^{\mathrm{g}}$ & $23.35 \pm 2.72^{\mathrm{h}}$ \\
\hline Tecoma garrocha & $135.18 \pm 1.69^{\mathrm{a}}$ & $1.76 \pm 0.003^{\mathrm{a}}$ & $84.10 \pm 1.96^{c}$ & $2.67 \pm 0.40^{c . d}$ \\
\hline Tecoma stans & $84.61 \pm 4.15^{\text {h.i }}$ & $10.27 \pm 0.37^{\mathrm{i}}$ & $63.85 \pm 4.26^{\mathrm{b}}$ & $1.23 \pm 0.11^{\mathrm{b} . c}$ \\
\hline
\end{tabular}

"Mean values \pm standard deviation. wf: white flowers; pf: pink flowers; GAE: Gallic Acid Equivalent; DE: Dry extract; QE: Quercetin equivalent. Different letters within a column indicate significant difference at $\mathrm{p}<0.05$. 
Table 2: Antibacterial activity, MIC and MBC ( $\mu \mathrm{g} \mathrm{GAE} / \mathrm{ml})$ values of tinctures against pathogenic bacteria

\begin{tabular}{|c|c|c|c|c|}
\hline Strains & C. bignonoides & H. pulcherrimus & T. nodosa & T. stans \\
\hline \multicolumn{5}{|l|}{ Gram positive } \\
\hline S. aureus ATCC 29213 & $250 / 500$ & $500 / 1000$ & $500 / 1000$ & $250 / 500$ \\
\hline S. aureus (F13) & $500 / 1000$ & $500 / 1000$ & $500 / \mathrm{R}$ & $500 / 1000$ \\
\hline S. aureus (F29) & $500 / \mathrm{R}$ & $500 / \mathrm{R}$ & $500 / \mathrm{R}$ & $500 / \mathrm{R}$ \\
\hline S. aureus (F32) & $500 / 1000$ & $500 / \mathrm{R}$ & $500 / \mathrm{R}$ & $500 / 1000$ \\
\hline S. aureus (F33) & $500 / \mathrm{R}$ & $500 / 1000$ & $500 / \mathrm{R}$ & $500 / 1000$ \\
\hline S. aureus (F22) & $1000 / \mathrm{R}$ & $1000 / \mathrm{R}$ & $1000 / \mathrm{R}$ & $1000 / \mathrm{R}$ \\
\hline S. aureus (F7) & $500 / \mathrm{R}$ & $500 / \mathrm{R}$ & $500 / \mathrm{R}$ & $500 / \mathrm{R}$ \\
\hline S. epidermidis ATCC 12228 & $250 / 1000$ & $500 / \mathrm{R}$ & $500 / \mathrm{R}$ & $125 / 1000$ \\
\hline E. faecalis ATCC 29212 & $1000 / \mathrm{R}$ & $1000 / 1000$ & $1000 / \mathrm{R}$ & $1000 / \mathrm{R}$ \\
\hline \multicolumn{5}{|l|}{ Gram negative } \\
\hline E. coli ATCC 35218 & $\mathrm{R}$ & $\mathrm{R}$ & $\mathrm{R}$ & $\mathrm{R}$ \\
\hline P. aeruginosa ATCC 27853 & $\mathrm{R}$ & $\mathrm{R}$ & $\mathrm{R}$ & $\mathrm{R}$ \\
\hline E. cloacae (F302) & $\mathrm{R}$ & $\mathrm{R}$ & $\mathrm{R}$ & $\mathrm{R}$ \\
\hline E. cloacae (F338) & $\mathrm{R}$ & $1000 / \mathrm{R}$ & $\mathrm{R}$ & $\mathrm{R}$ \\
\hline K. pneumoniae (F364) & $\mathrm{R}$ & $\mathrm{R}$ & $\mathrm{R}$ & $\mathrm{R}$ \\
\hline M. morganii (F339) & $1000 / \mathrm{R}$ & $\mathrm{R}$ & $\mathrm{R}$ & $1000 / \mathrm{R}$ \\
\hline P. aeruginosa (F305) & $\mathrm{R}$ & $\mathrm{R}$ & $\mathrm{R}$ & $\mathrm{R}$ \\
\hline P. mirabilis (F304) & $1000 / \mathrm{R}$ & $1000 / \mathrm{R}$ & $\mathrm{R}$ & $1000 / \mathrm{R}$ \\
\hline
\end{tabular}

R: Resistant; not detected within the tested concentrations (62.5 to $1000 \mu \mathrm{g} \mathrm{GAE} / \mathrm{ml}$ ).

hibitory concentration) index was then calculated as the sum of each component FIC in a combination and interpreted as either synergistic $(\leq 0.5)$, additive $(>0.5$ and $\leq 1.0)$, indifferent $(>1$ and $\leq 4.0)$ or antagonistic $(>4.0) .{ }^{18}$ The assays were performed in triplicate and as independent tests; mean values were calculated.

\section{RESULTS}

Alkaloids were only detected in leaves of Tecoma stans while saponins were not detected, but all the plants showed the presence of terpenoids, phenols and flavonoids. The results of the total phenolics and flavonoids content are presented in Table 1.

The qualitative screening of antimicrobial activity showed that $30 \mu \mathrm{g}$ of phenolic compounds from infusions were not active whereas the same amount of ethanolic extracts of many plants were able to inhibit bacterial growth. The tinctures of C. bignonioides, H. pulcherrimus, Tabebuia nodosa and Tecoma stans were selected for the determination of MIC, MBC values and synergistic effect. The four extracts were active in varying degrees against Gram-positive strains. Catalpa and Tecoma inhibited the growth of Proteus and Morganella morganii, Handroanthus was active against $P$. mirabilis and one clinical isolate of E. cloacae, while Tabebuia had no effect against Gram-negative bacteria (Table 2).

In the time-kill assay, the extracts significantly inhibited bacterial growth when compared with the growth control; however, the reduction in growth was $\leq 3 \log _{10} \mathrm{CFU} / \mathrm{ml}$ for all isolates, indicating a bacteriostatic effect (Figure 1).

FIC indices for extracts and antibiotic combinations-calculated according to the checkerboard test- are shown in Tables 3 and 4 . The combination of the extracts with oxacillin diminished the MIC values of antibiotic against methicillin resistant clinical isolates of Staphylococcus (F7 and F22). The MIC value of the oxacillin against strain F7 was $25.6 \mu \mathrm{g} / \mathrm{ml}$ and $204.8 \mu \mathrm{g} / \mathrm{ml}$ for strain F22 (Table 3). However, in the combinations with extracts, the antibiotic concentrations required to obtain the same effect

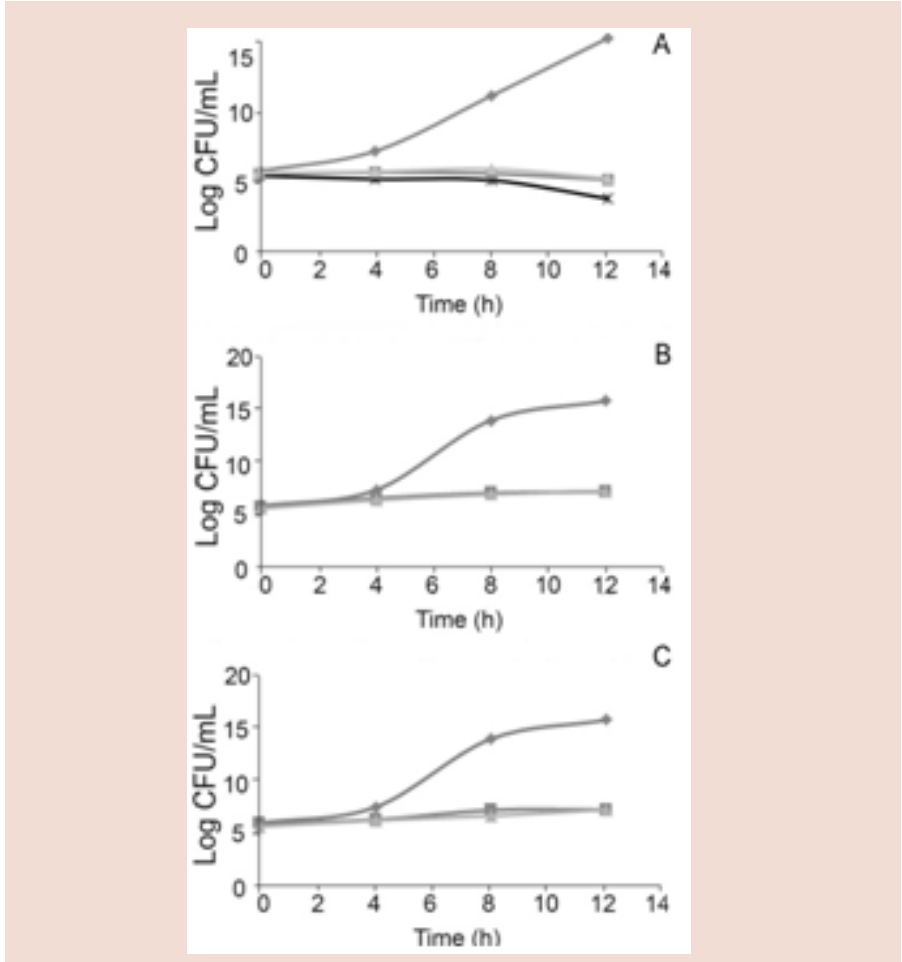

Figure 1: Time kill assay of A) S. aureus, B) M. morganii and C) P. mirabilis in presence of Tecoma stans extract. Control (rhombus), MIC (triangle), 2MIC (square) and 4MIC (cross).

were much lower (sometimes 16-32 times lower). Morganella morganii, $K$. pneumoniae and $P$. mirabilis were the most sensitive to combinations within Gram negative bacteria isolates (Table 4). The best combination 


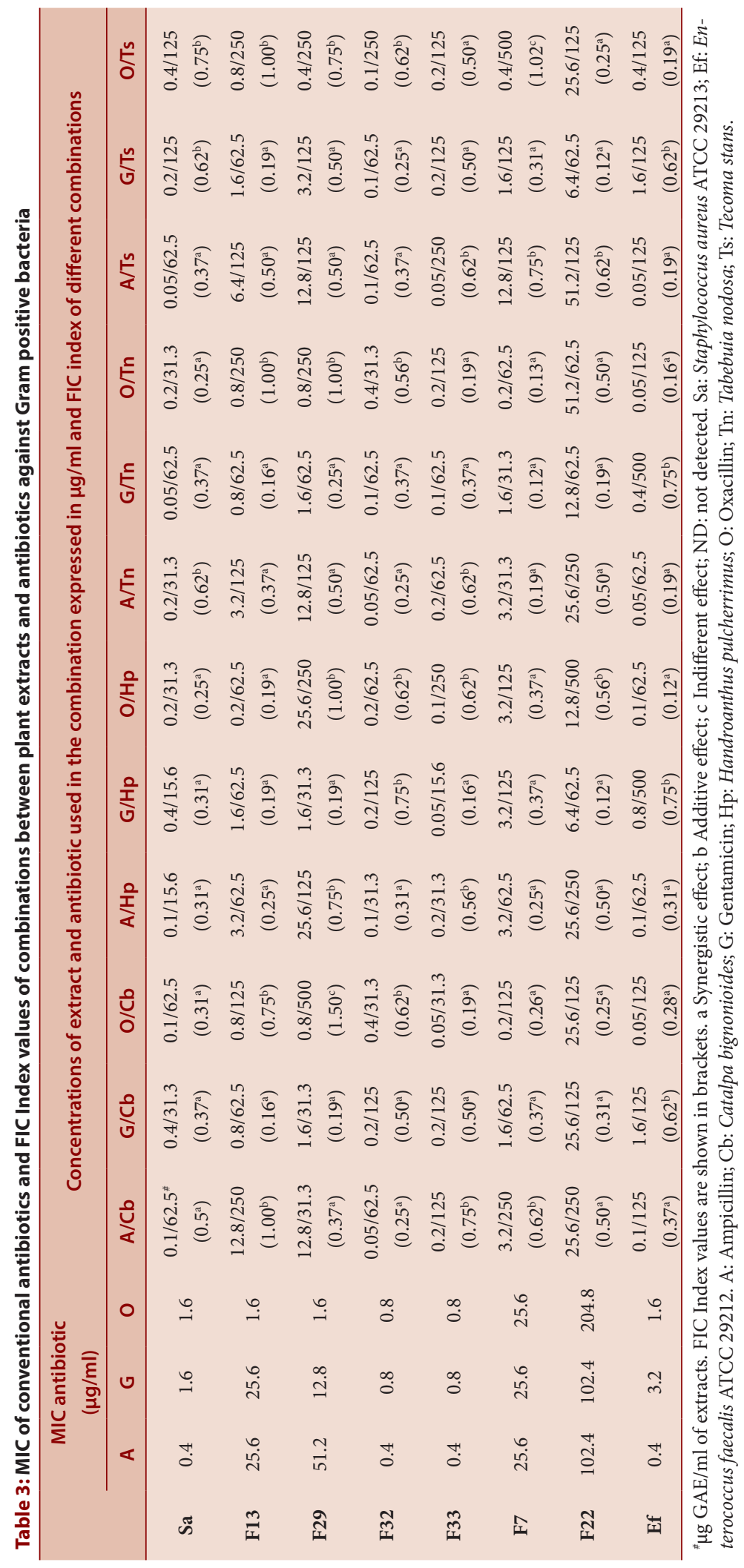

\section{DISCUSSION}

was T. nodosa extract and gentamicin, synergism obtained in $81.25 \%$ of bacteria tested. Only the combination of Tecoma stans extract and ampicillin had a synergistic effect for both clinical isolates of E. cloacae. No antagonism was observed for any of the combinations evaluated.
The tinctures tested had higher antibacterial activity against Gram positive bacteria than against Gram negative ones. The latter bacteria are usually less susceptible to the action of plant extracts. ${ }^{19,20}$ However, it is noteworthy that among the species studied in this work C. bignonioides, 
Table 4: MIC of conventional antibiotics and FIC Index values of combinations between plant extracts and antibiotics against Gram negative bacteria

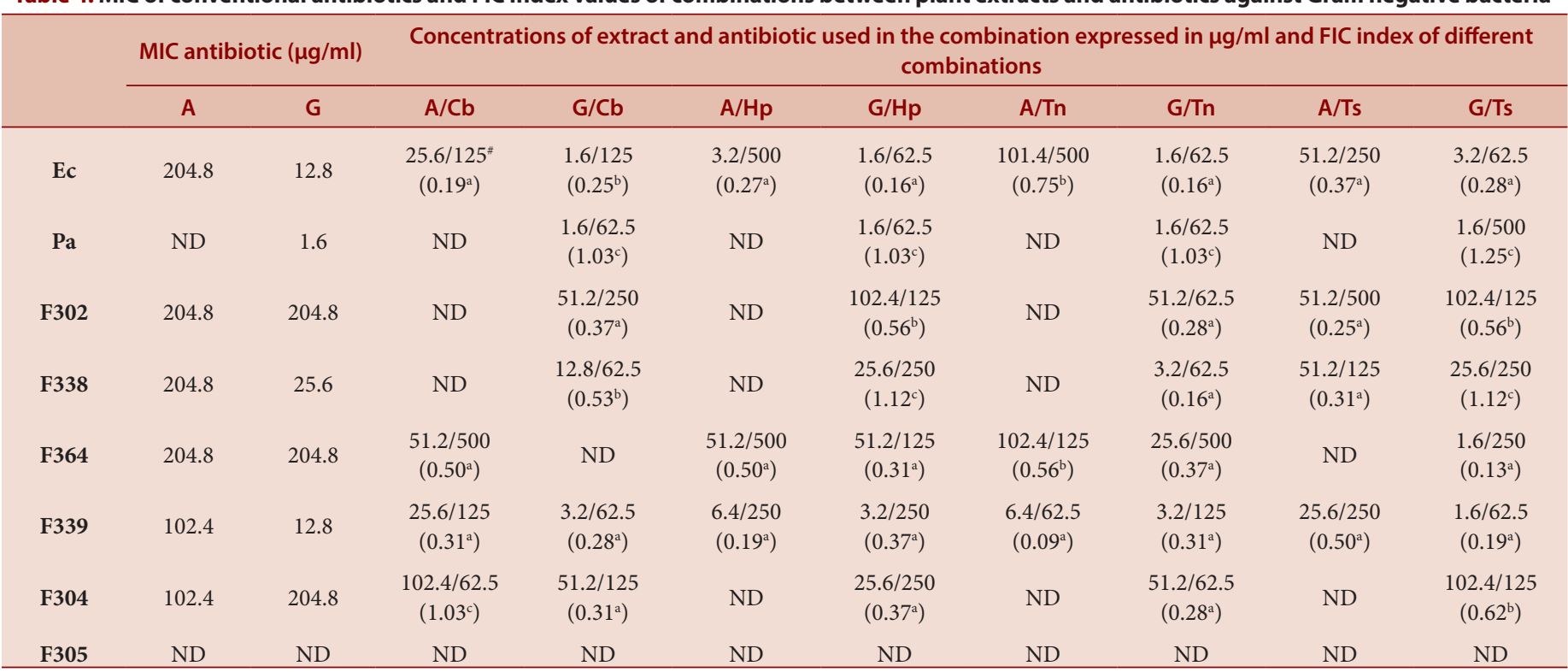

${ }^{*} \mu \mathrm{g}$ GAE/ml of extracts. FIC Index values are shown in brackets. a) Synergistic effect; b) Additive effect; c) Indifferent effect; ND: Not detected. Ec: Escherichia coli ATCC 35218; Pa: Pseudomonas aeruginosa ATCC 27853. A: Ampicillin; Cb: Catalpa bignonioides; G: Gentamicin; Hp: Handroanthus pulcherrimus; O: Oxacillin; Tn:

Tabebuia nodosa; Ts: Tecoma stans.

H. pulcherrimus and T. stans were able to inhibit the growth of some Gram negative strains.

Some studies have demonstrated that plants of the Handroanthus genus have antibacterial activity against Helicobacter pylori ${ }^{21}$ and $S$. aureus. ${ }^{22}$ Most of these results referred to studies carried out on barks, while this work considered leaves as the objects of study. Though, different extracts of leaves of T. stans have been reported for antimicrobial effects on some human pathogenic bacteria, ${ }^{7,19,23,24}$ which partially support our results.

The results of synergism tests suggest the potential use of some of these plants to improve the effect of antibiotics. MIC values were reduced 1632 times for antibiotics, in most cases, and even eight or sixteen times for extracts, depending on the tested bacterium. No antagonism was observed for any of the combinations evaluated and when indifference or additivity were observed, a substantial decrease in the MIC of the antibiotic in the combination was detected, while the MIC extract remained unchanged or decreased only 2 times. These data are also relevant. Although no synergism was observed for these combinations, they decreased the dose of the antibiotic with a consequent reduction of side effects.

The interaction of plant extracts with antibiotics is one of the novel ways to overcome the resistance mechanisms of bacteria. Several studies on the interaction between plant extracts and antibiotics indicated a synergistic interaction with antibiotics. ${ }^{25,26}$

It is remarkable that, to our knowledge, there are not data in worldwide literature about studies of synergism between these species and commercial antibiotics. Our results revealed that some of the combinations selected can effectively inhibit the growth of tested strains at lower concentrations than those required for the individual agents.

\section{CONCLUSION}

The results suggest that the extracts of the studied Bignoniaceae species possess some compounds with antimicrobial properties; besides, they could enhance the efficacy of antibiotics against resistant bacteria. Consequently, these extracts could be used as antimicrobial agents for infectious diseases therapy in humans. Chemical studies are required to determine the compounds responsible for antibacterial effect of these species in leaves; in this sense, investigations to identify the structures of active principles are being conducted in our laboratory.

\section{ACKNOWLEDGEMENT}

We are grateful to CONICET and Universidad Nacional del Chaco Austral (UNCAus, Argentina) for their financial support. We thank M. M. Arbo of the IBONE for plant identification.

\section{CONFLICT OF INTEREST}

The authors have no conflicts of interest to declare.

\section{REFERENCES}

1. Hemaiswarya SH, Kruthiventi AK, Doble M. Synergism between natural products and antibiotics against diseases. Phytomed. 2008; 15(8): 639-52.

2. Alonso J, Desmarchelier C. Indigenous medicinal plants Argentina: scientific bases for use in primary health care [Plantas medicinales autóctonas de la Argentina: bases científicas para su aplicación en atención primaria de la salud]. $1^{\text {st }}$ ed. Buenos Aires: Fitociencia; 2006.

3. Bastos ML, Lima MRF, Conserva LM, Andrade VS, Rocha EMM, Lemos RPL. Studies on the antimicrobial activity and brine shrimp toxicity of Zeyheria tuberculosa (Vell.) Bur. (Bignoniaceace) extracts and their main constituents. Ann Clin Microbiol. Antimicrob. 2009; 8(1): 16

4. Agra MF, Baracho GS, Nurit K, Basilio IJ, Coelho VP. Medicinal and poisonous diversity of the flora of Cariri paraibano. Brazil. J Ethnopharmacol. 2007; 111(2): 383-95.

5. Gómez Castellanos JR, Prieto JM, Heinrich M. Red Lapacho (Tabebuia impetiginosa)-A global ethnopharmacological commodity?. J Ethnopharmacol. 2009; 121(1): 1-13.

6. Castillo L, Rossini C. Bignoniaceae metabolites as semiochemicals. Molecules 2010; 15(10): 7090-105

7. Senthil kumar CS, Suresh kumar M, Pandian MR. In vitro antibacterial activity of crude leaf extracts from Tecoma stans (L.) Juss. exKunth, Colues forskohlii and Pogostemon patchouli against human pathogenic bacteria. Int J Pharm Tech Res. 2010; 2(1): 438-42.

8. Torres CA, Zampini IC, Nuñez MB, Isla MI, Castro MP, Gonzalez AM. In vitro antimicrobial activity of 20 selected climber species from the Bignoniaceae family. Nat Prod Res. 2013; 27(22): 2144-8.

9. Dominguez $X$. Phytochemical research methods [Métodos de investigación fitoquímica]. México: Limusa; 1988

10. Wagner H, Bladt S. Plant Drug Analysis: A Thin Layer Chromatography Atlas Berlin: Springer-Verlag; 1996. 
11. Singleton $V$, Orthofer R, Lamuela-Raventos R. Analysis of total phenols and other oxidation susbstrates and antioxidants by means of Folin Ciocalteu reagent. Methods Enzimol. 1999; 299 (1): 152-78.

12. Woisky RG, Salatino A. Analysis of propolis: some parameters and procedures for chemical quality control. J Apic Res. 1998; 37(2): 99-105.

13. Clinical and Laboratory Standards Institute (CLSI). Performance standards for antimicrobial disk susceptibility tests; M2-A9. 26:1. Wayne, PA: CLSI; 2006.

14. Nieva Moreno MI, Isla MI, Cudmani NG, Vattuone MA, Sampietro AR. Screening of antibacterial activity of Amaicha del Valle (Tucuman, Argentina) propolis. J Ethnopharmacol. 1999; 68(1): 97-102.

15. Clinical and Laboratory Standards Institute (CLSI). Methods for dilution antimicrobial susceptibility tests for bacteria that grow aerobically; M7-A7. Wayne, PA: CLSI; 2006.

16. Chattopadhyay D, Mukherjee T, Pal P, Saha B, Bhadra R. Altered membrane permeability as the basis of bactericidal action of methdilazine. J Antimicrob Chemother. 1998; 42(1): 83-6.

17. Moody J. Synergism testing: Broth microdilution checkerboard and broth macrodilution methods. In: Isenberg Henry D, García Lynne S, editors. Clinical Microbiology Procedures Handbook. Washington D.C: ASM Press; 2007. 5.12.1-23.

18. Schelz Z, Molnar J, Hohmann J. Antimicrobial and antiplasmid activities of essential oils. Fitoterapia 2006; 77(4): 279-85.

19. Salem MZM, GoharYM, Camacho LM, El-Shanhorey NA, Salem AZM. Antioxidant and antibacterial activities of leaves and branches extracts of Tecoma stans (L.)
Juss. Ex Kunth against nine species of pathogenic bacteria. Afr. J. Microbiol. Res. 2013; 7(5): 418-26.

20. Pagès JM, James CE, Winterhalter $M$. The porin and the permeating antibiotic: a selective diffusion barrier in Gram-negative bacteria. Nat. Rev. Microbiol. 2008; 6(12): 893-903.

21. Park BS, Lee HK, Lee SE, Piao XL, Takeoka GR, Wong RY, et al. Antibacterial activity of Tabebuia impetiginosa Martius ex DC (Taheebo) against Helicobacter pylori. J. Ethnopharmacol. 2006; 105(1): 255-62.

22. Martínez M, Mancuello C, Brítez F, Pereira C, Arrúa J, Franco G, et al. Caracterización química y actividades biológicas de lapachol aislado de Handroanthus heptaphyllus (Vell.) Mattos. Steviana 2012; 4: 47-64.

23. Singh V, Kumar L, Chakraborthy GS, Mazumder A. Pharmacological and phytochemical findings of Tecoma stans- a review. Japhr. 2011 Jan; 1(3): 75-81.

24. Govindappa M, Sadananda TS, Channabasava R, Vinay VR. In vitro anti-inflammatory, lipoxygenase, xanthine oxidase and acetycholinesterase inhibitory activity of Tecoma stans (L.) Juss. Ex Kunth. Int. J. Pharm. Bio Sci. 2011; 2(2): 276-85.

25. Rosato A, Vitali C, De Laurentis N, Armenise D, Antonietta Milillo M. Antibacterial effect of some essential oils administered alone or in combination with norfloxacin Phytomed. 2007; 14(11): 727-32.

26. Olajuyigbe $\mathrm{OO}$, Afolayan AJ. Evaluation of combination effects of ethanolic extract of Ziziphus mucronata Willd. subsp. Mucronata Willd. and antibiotics against clinically important bacteria. Scientific World Journal 2013. http://dx.doi. org/10.1155/2013/769594

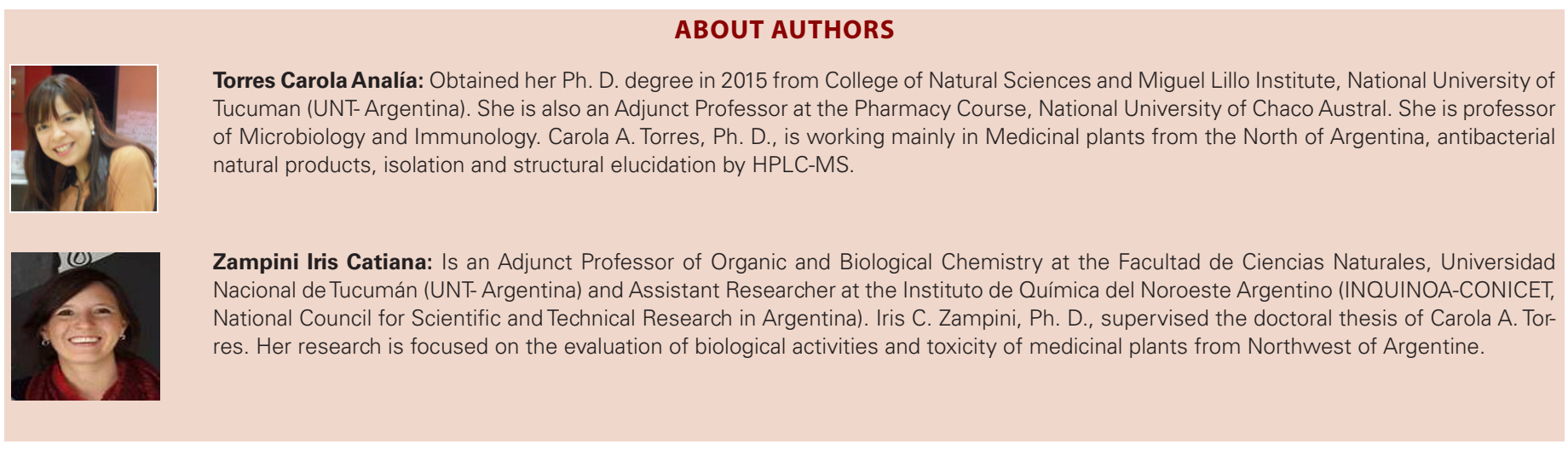

